Acta Crystallographica Section D

\section{Biological \\ Crystallography}

ISSN 0907-4449

\title{
Expression, purification and preliminary crystallographic analysis of dipeptidyl peptidase IV from Porphyromonas gingivalis
}

The asaccharolytic periodontopathogen Porphyromonas gingivalis produces membrane-anchored proteases such as dipeptidyl peptidase

Received 1 June 2004 Accepted 17 July 2004

\section{Dean Rea, ${ }^{a}$ Anne-Marie Lambeir, ${ }^{\text {b }}$ Yumi Kumagai, ${ }^{c}$ Ingrid De Meester, ${ }^{b}$ Simon Scharpéb and Vilmos Fülöp ${ }^{\mathrm{a} *}$}

\author{
${ }^{a}$ Department of Biological Sciences, University \\ of Warwick, Gibbet Hill Road, Coventry \\ CV4 7AL, England, 'b Department of Pharma- \\ ceutical Sciences, University of Antwerp, \\ Universiteitsplein 1, Wilrijk, Belgium, and \\ 'Department of Microbiology, Nippon Dental \\ University, Tokyo, Japan
}

Correspondence e-mail:

vilmos@globin.bio.warwick.ac.uk
C) 2004 International Union of Crystallography Printed in Denmark - all rights reserved

IV that are involved in the destruction of host periodontal tissue. The extracellular domain of this enzyme was overexpressed in Escherichia coli as an N-terminal His-tag fusion protein, purified using standard metal-affinity chromatography and crystallized using the hangingdrop vapour-diffusion technique in $40 \%$ 2-methyl-2,4-pentanediol and $100 \mathrm{~m} M$ Tris- $\mathrm{HCl} \mathrm{pH}$ 8.0. Diffraction data to $2.7 \AA$ resolution were collected using synchrotron radiation. The crystals belong to space group $P 2_{1}$, with unit-cell parameters $a=117.0, b=112.9$, $c=310.0 \AA, \beta=95.0^{\circ}$. There are ten molecules per asymmetric unit, indicating a solvent content of $50 \%$. Data were also collected from selenomethionine-derived crystals and structure solution by SAD or MAD is in progress.

\section{Introduction}

Porphyromonas gingivalis is a major pathogen associated with adult periodontitis (Holt et al., 1988; Allaker \& Hardie, 1998; Genco et al., 1998). This organism is also implicated in systemic diseases such as aspiration pneumonia in the elderly and in endocarditis and pulmonary infections as a blood-borne pathogen (Allaker \& Hardie, 1998; Allen \& Duerden, 1998; Genco et al., 1998; Read \& Finch, 1998). It is not known at present how oral bacteria are able to penetrate the systemic circulation and cause infection at sites other than the oral cavity.

$P$. gingivalis is asaccharolytic and cannot take up free amino acids, utilizing only short oligopeptides as carbon and energy sources (Dashper et al., 1998). A complex cell-surfaceassociated proteolytic system comprising several unique peptidases has evolved to meet this nutritional requirement. The best characterized of these enzymes are gingipains $R$ and $\mathrm{K}$, which are arginine and lysine-specific cysteine proteases, respectively (Curtis et al., 1999). These and other cysteine proteases are involved in degrading the periodontal ligament and surrounding area (Potempa et al., 1995; Travis et al., 1997). The gingival connective tissue is comprised predominantly of collagen type I, which can be degraded by human and bacterial collagenases. The resulting fragments are then susceptible to further degradation by endopeptidases released by plaque bacteria. These collagen-derived peptides are rich in proline and hydroxyproline, making them resistant to hydrolysis by most proteases. For asaccharolytic organisms, the ability to process these peptides is important for providing nutrients. A number of serine proteases from $P$. gingivalis have been identified that possess the ability to hydrolyse peptides at proline residues. A post-proline endopeptidase showing homology to human angiotensinconverting enzyme has been described (Awano et al., 1999). A pair of post-proline exopeptidases belonging to the prolyl oligopeptidase family have been discussed, namely prolyl tripeptidyl peptidase (PtpA) and dipeptidyl peptidase IV (DPPIV; Banbula et al., 1999, 2000; Kumagai et al., 2000). Both enzymes contain a catalytic serine residue within the sequence $\mathrm{G} X \mathrm{~S} X \mathrm{GG}$, the consensus sequence for this enzyme family, where $X$ is any amino acid (Rawlings et al., 1991)

$P$. gingivalis has the ability to survive on dipeptides as the sole source of carbon, suggesting an important nutritional function for DPPIV (Takahashi \& Sato, 2001, 2002). An animal study involving the use of a DPPIVdeficient knockout mutant of the bacterium has shown this enzyme to be a potential virulence factor (Kumagai et al., 2000). Mice infected with the DPPIV-deficient strain became infected less severely and recovered more quickly from infection than those infected with the wild-type bacterium (Kumagai et al., 2000; Yagashita et al., 2001). Reintroduction of the cloned DPPIV gene into the null mutant using a shuttle vector restored virulence (Kumagai et al., 2003). Expression of the catalytically deficient DPPIV enzyme in which the catalytic serine is mutated to alanine results in an intermediate virulence between the strain expressing wild-type DPPIV and the null mutant. This indicates that DPPIV cata- 
lytic activity is important but not sufficient for virulence (Kumagai et al., 2003).

DPPIV is also found in eukaryotes, where soluble and membrane-anchored forms have been characterized. Although the physiological and pathological roles of the bacterial protein are not well understood, a wealth of literature exists concerning the biological role of the mammalian enzyme. It has the ability to degrade a range of signalling peptides, including chemokines and neuropeptides (Augustyns et al., 1999; Lambeir, Durinx et al., 2001; Lambeir, Proost et al., 2001). In addition to enzymatic activity, eukaryotic DPPIV is involved in protein-protein interactions with collagen and/or fibronectin (Kikkawa et al., 2003) and adenosine deaminase (Abbott et al., 1999). The enzyme has been implicated in a number of disease states, including AIDS, breast cancer and diabetes (Gutheil et al., 1994; Wrenger et al., 1997; Cheng et al., 1998; Ohtsuki et al., 1998; Augustyns et al., 1999). It is possible that $P$. gingivalis DPPIV (PgDPPIV) not only helps to fulfil a nutritional requirement, but is also capable of hydrolysing chemokines and other host peptides, helping to evade the host's response to infection.

Kinetic studies revealed similarities and differences between the enzymatic properties of eukaryotic and bacterial DPPIV (Lambeir et al., 2003). Differences in inactivation kinetics using dipeptide-derived diaryl-phosphonate esters suggest there are significant structural differences in the active sites. A different residue is preferred at the P2 position of the substrate (Lambeir et al., 2003). The crystal structures of both human and porcine DPPIV have been solved (Engel et al., 2003; Hiramatsu et al., 2003; Oefner et al., 2003; Rasmussen et al., 2003; Thoma et al., 2003). The overall structure is reminiscent of the closely related prolyl oligopeptidase (Fülöp et al., 1998). The catalytic domain has $\alpha / \beta$-hydrolase topology and is structurally homologous to lipases and esterases. There is a further opentopology $\beta$-propeller domain that is eightbladed in DPPIV but seven-bladed in prolyl oligopeptidase (Fülöp et al., 1998). Whilst prolyl oligopeptidase is monomeric, both eukaryotic and bacterial DPPIV enzymes exist as dimers. PgDPPIV exhibits around $28 \%$ sequence identity to its eukaryotic counterparts, so a similar overall threedimensional structure would be anticipated. The crystal structure of the bacterial enzyme may help to explain the observed enzymatic differences and assist in the development of selective inhibitors for the treatment of periodontitis.

\section{Materials and methods}

\subsection{Cloning, overexpression and purification}

A plasmid containing the PgDPPIV gene was used as published previously (Kumagai et al., 2000). The region of the gene corresponding to the extracellular part of the protein (starting at glutamine 20) was amplified by PCR with primers incorporating $N c o$ I and EcoRI sites at the $5^{\prime}$ and $3^{\prime}$ ends, respectively. The resulting PCR fragment was digested with these enzymes and ligated into the pProEx-Hta expression vector. Positive recombinants were selected and the expression plasmid was used to transform the Echerichia coli BL21(DE3) expression strain, which also contained the pRARE plasmid for supplementation of rare tRNAs. Bacteria were grown at $310 \mathrm{~K}$ in $21 \mathrm{LB}$ medium containing $100 \mu \mathrm{g} \mathrm{ml}^{-1}$ ampicillin and $35 \mu \mathrm{g} \mathrm{ml}^{-1}$ chloramphenicol. Protein expression was induced by the addition of IPTG to $1 \mathrm{~m} M$ and growth continued at $293 \mathrm{~K}$ for $18 \mathrm{~h}$. The cells were harvested by centrifugation at $6000 \mathrm{~g}$ for $15 \mathrm{~min}$ and resuspended in $50 \mathrm{~m} M$ HEPES $\mathrm{pH}$ 8.0, $1 M \mathrm{NaCl}, 10 \mathrm{~m} M$ imidazole (buffer $A$ ) prior to sonication and clarification of the extract by centrifugation at $20000 \mathrm{~g}$ for $30 \mathrm{~min}$. The $\mathrm{N}$-terminal histidine-tagged recombinant enzyme was purified in one step using nickel-affinity chromatography. A nickel Sepharose column was equilibrated in buffer $A$. The cell extract was applied, the column was washed with buffer $A$, buffer $B$ (50 $\mathrm{m} M$ HEPES pH 8.0, $1 M \mathrm{NaCl}, 100 \mathrm{~m} M$ imidazole) and buffer $C(50 \mathrm{~m} M$ HEPES $\mathrm{pH}$ 8.0, $0.1 M \mathrm{NaCl}, 100 \mathrm{~m} M$ imidazole) and the enzyme was eluted with buffer $D(50 \mathrm{~m} M$ HEPES pH 8.0, $0.1 M \mathrm{NaCl}, 500 \mathrm{~m} M$ imidazole). Fractions containing protein were combined, diluted twofold with elution buffer and glycerol was added to $20 \%(v / v)$ to prevent aggregation. The sample was concentrated using centrifugal concentrators and applied onto a Hi-trap desalting column equilibrated with $20 \mathrm{~m} M$ Tris- $\mathrm{HCl} \mathrm{pH} 8.5$,

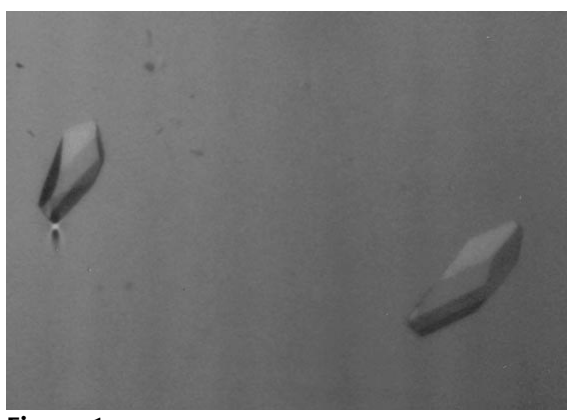

Figure 1

Photograph of a PgDPPIV crystal; the largest crystal dimension is $0.3 \mathrm{~mm}$.
$20 \%$ glycerol. DPPIV was judged by Coomassie-stained SDS-PAGE to be greater than $99 \%$ pure and was concentrated to $9 \mathrm{mg} \mathrm{ml}^{-1}$ prior to crystallization.

\subsection{Expression of selenomethionine- substituted PgDPPIV}

For the production of selenomethionine (SeMet) substituted PgDPPIV, the expression construct was used to transform the methionine auxotrophic E. coli strain B834(DE3) and a $5 \mathrm{ml}$ culture was grown overnight at $303 \mathrm{~K}$ in LB medium containing $100 \mu \mathrm{g} \mathrm{ml}^{-1}$ ampicillin. $100 \mathrm{ml} \mathrm{LB}$ was inoculated with $1 \mathrm{ml}$ overnight culture and grown at $310 \mathrm{~K}$ to an $\mathrm{OD}_{600}$ of 0.2 ; the cells were pelleted using centrifugation, resuspended in M9 minimal media, pelleted and resuspended twice more to remove SeMet. The cell suspension was used to inoculate 11 pre-warmed $(310 \mathrm{~K})$ M9 minimal media supplemented with $0.4 \%$ glucose, $40 \mathrm{mg} \mathrm{l}^{-1}$ of 19 amino acids (all except Met), $40 \mathrm{mg} \mathrm{l}^{-1}$ SeMet, $1 \mathrm{mg} \mathrm{l}^{-1}$ of the vitamins thiamine, thymine, niacinamide and pyridoxine monohydrochloride, $25 \mathrm{mg} \mathrm{l}^{-1}$ iron (II) sulfate and $2 \mathrm{~m} M$ magnesium sulfate. The culture was grown to an $\mathrm{OD}_{600}$ of 0.6 , protein expression was induced by addition of IPTG to $1 \mathrm{~m} M$ and growth continued at 293 K for 16 h. SeMet-substituted PgDPPIV was purified as described above, except that 2-mercaptoethanol was used at $2 \mathrm{mM}$ in all buffers.

\subsection{Crystallization}

Initial crystallization screens were performed using the hanging-drop vapourdiffusion technique with $0.5 \mathrm{ml}$ reservoir solutions taken from Hampton Research Crystal Screens I and II (Jancarik \& Kim, 1991) or the Clear Strategy Screen buffered at $0.1 M$ MES pH 6.5 (Brzozowski \& Walton, 2001). Clusters of plate-like crystals appeared after several months in a solution containing $40 \%(v / v)$ MPD, $100 \mathrm{~m} M$ Tris $\mathrm{pH}$ 7.5. Using the microseeding technique, single crystals suitable for X-ray diffraction studies were grown in a solution containing between 35 and 40\%(v/v) MPD, $100 \mathrm{mM}$ Tris pH 8.0 and had dimensions of $0.1 \times 0.2$ $\times \quad 0.3 \mathrm{~mm}$ (Fig. 1). SeMet-substituted PgDPPIV crystals grew under identical conditions.

\subsection{X-ray diffraction analysis}

Crystals were picked up from the crystallization drop using a nylon loop, transferred directly into a cryostream, cooled to $100 \mathrm{~K}$ and then stored in liquid nitrogen 


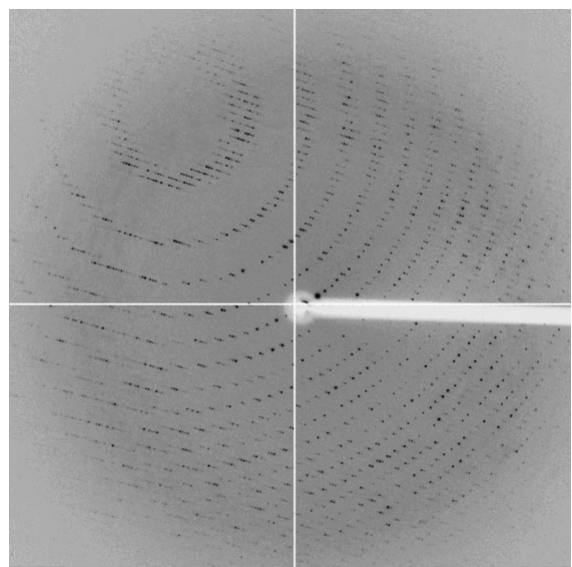

Figure 2

A typical diffraction image of a selenomethioninesubstituted crystal collected at beamline ID14-4 at the ESRF using an ADSC Q4 CCD detector. The oscillation range was $0.5^{\circ}$ and the resolution at the edge is $2.4 \AA$.

until needed for data collection. A partial data set was collected from native crystals to a resolution of $2.8 \AA$ with an oscillation range of $1^{\circ}$ per frame on beamline 14.1 at the SRS, Daresbury using an ADSC Q4 $\mathrm{CCD}$ detector. All data were indexed, integrated and scaled using the $H K L$ suite of programs (Otwinowski \& Minor, 1997). The crystals belong to space group $P 2_{1}$, with unitcell parameters $a=117.0, b=112.9$, $c=310.0 \AA, \beta=95.0^{\circ}$, resulting in a unit-cell volume of $4.1 \times 10^{6} \AA^{3}$. The Matthews probability calculation suggests the presence of ten molecules in the asymmetric unit with a $V_{\mathrm{M}}$ value of $2.46 \AA^{3} \mathrm{Da}^{-1}$, corresponding to a solvent content of $50 \%$. The structures of both human and porcine DPPIV have been solved. However, the $P$. gingivalis enzyme shares only $28 \%$ sequence identity with both the porcine and human proteins. Low sequence homology coupled with the large number of molecules in the asymmetric unit resulted in the unsurprising failure of molecular replacement using either monomeric or dimeric eukaryotic DPPIV coordinates as search models. Selenomethionine-derived crystals have been prepared and data were collected to $2.7 \AA$ at three wavelengths on beamline ID14-4 at the ESRF, Grenoble. A typical diffraction image is shown in Fig. 2. All data were indexed, integrated and scaled with the HKL package (Otwinowski \& Minor, 1997). Data-collection and processing statistics for highly redundant (11.5-fold) data collected at the selenium absorption-peak wavelength are shown in Table 1 . Structure solution by $\mathrm{SAD}$ or MAD is in progress and heavy-atom soaks are under way to provide additional phasing options.
Table 1

Data-collection and processing statistics.

Data were collected at the wavelength of the selenium absorption peak. Values in parentheses refer to the highest resolution shell.

\begin{tabular}{ll}
\hline Synchrotron radiation & ESRF ID14-14 \\
Detector & ADSC Q4 CCD \\
Wavelength $(\AA)$ & 0.9794 \\
Space group & $P 2_{1}$ \\
Unit-cell parameters & \\
$\quad a(\AA)$ & 117.0 \\
$\quad b(\AA)$ & 112.9 \\
$\quad c(\AA)$ & 311.0 \\
$\beta\left({ }^{\circ}\right)$ & 95.0 \\
Molecules per AU & 10 \\
Matthews coefficient $\left(\AA^{3} \mathrm{Da}^{-1}\right)$ & 2.46 \\
Solvent convent $(\%)$ & 50 \\
Resolution range $(\AA)$ & $80-2.7(2.8-2.7)$ \\
Total observations & 9885450 \\
Unique reflections & 425879 \\
Average $I / \sigma(I)$ & $14.7(2.4)$ \\
$R_{\text {merge }}(\%)$ & $0.062(0.231)$ \\
Completeness $(\%)$ & $97.8(99.9)$ \\
\hline
\end{tabular}

We are grateful for access and user support at the synchrotron facilities of ESRF, Grenoble and SRS, Daresbury. DR thanks the BBSRC for the award of a studentship. VF is a Royal Society University Research Fellow.

\section{References}

Abbott, C. A., McCaughan, G. W., Levy, M. T., Church, W. B. \& Gorrell, M. D. (1999). Eur. J. Biochem. 266, 798-810.

Allaker, R. P. \& Hardie, J. M. (1998). Topley and Wilson's Principles of Bacteriology, Virology and Immunity, 9th ed., edited by W. J. Hausler \& M. Sussman, Vol. 3, pp. 373-390. London: Arnold.

Allen, S. D. \& Duerden, B. I. (1998). Topley and Wilson's Principles of Bacteriology, Virology and Immunity, 9th ed., edited by W. J. Hausler \& M. Sussman, Vol. 3, pp. 743-776. London: Arnold.

Augustyns, K., Bal, G., Thonus, A., Belyaev, X. M., Zhang, W., Bollaert, W., Lambeir, A. M., Durinx, C., Goosens, F. \& Haemers, A. (1999). Curr. Med. Chem. 6, 311-327.

Awano, S., Ansai, T., Mochizuki, H., Yu, W., Tanzanawa, K., Turner, A. J. \& Takehara, T. (1999). FEBS Lett. 460, 139-144.

Banbula, A., Bugno, M., Goldstein, J., Yen, J., Nelson, D., Travis, J. \& Potempa, J. (2000). Infect. Immun. 68, 1176-1182.

Banbula, A., Mak, P., Bugno, M., Silberring, J., Dubin, A., Nelson, D., Travis, J. \& Potempa, J. (1999). J. Biol. Chem. 274, 9246-9252.

Brzozowski, A. M. \& Walton, J. (2001). J. Appl. Cryst. 34, 97-101.

Cheng, H. C., Abdel-Ghany, M., Elble, R. C. \& Pauli, B. U. (1998). J. Biol. Chem. 273, 2420724215.

Curtis, M. A., Kuramitsu, H. K., Lantz, M., Macrina, F. L., Nakayama, K., Potempa, J., Reynolds, E. C. \& Aduse-Opuku, J. (1999). J. Periodontal Res. 34, 464-472.

Dashper, S. G., Kandasamy, S., O'Brien-Simpson, N. \& Reynolds, E. C. (1998). J. Dent. Res. 77, 1133.
Engel, M., Hoffmann, T., Wagner, L., Wermann, M., Heiser, U., Kiefersauer, R., Huber, R., Bode, W., Demuth, H. U. \& Brandstetter, H. (2003). Proc. Natl Acad. Sci. USA, 100, 50635068.

Fülöp, V., Böcskei, Z. \& Polgár, L. (1998). Cell, 94, 161-170.

Genco, C. A., Van Dyke, T. \& Amar, S. (1998). Trends Microbiol. 6, 444-449.

Gutheil, W. G., Subramanyam, G. R., Flentke, G. R., Sanford, D. G., Munoz, E., Huber, B. T. \& Bachovin, W. W. (1994). Proc. Natl Acad. Sci. USA, 91, 6594-6598.

Hiramatsu, H., Kyono, K., Higashiyama, Y., Fukushima, C., Shima, H., Sugiyama, S., Inaka, K., Yamamoto, A. \& Shimizu, R. (2003). Biochem. Biophys. Res. Commun. 302, 849-854.

Holt, S. C., Ebersle, J., Felton, M., Brunsvold, M. \& Kornman, K. S. (1988). Science, 239, 55-57.

Jancarik, J. \& Kim, S.-H. (1991). J. Appl. Cryst. 24, 409-411.

Kikkawa, F., Kajiyama, H., Ino, K., Shibata, K. \& Mizutani, S. (2003). Int. J. Cancer, 105, 779-783.

Kumagai, Y., Konishi, K., Gomi, T., Yagashita, H., Yajima, A. \& Yoshikawa, M. (2000). Infect. Immun. 68, 716-724.

Kumagai, Y., Yajima, A. \& Konishi, K. (2003). Microbiol. Immunol. 47, 735-743.

Lambeir, A. M., Durinx, C., Proost, P., Van Damme, J., Scharpé, S. \& de Meester, I. (2001). FEBS Lett. 507, 327-330.

Lambeir, A. M., Proost, P., Durinx, C., Bal, G., Senten, K., Augustyns, K., Scharpé, S., Van Damme, J. \& de Meester, I. (2001). J. Biol. Chem. 276, 29839-29845.

Lambeir, A. M., Rea, D., Fülöp, V., Kumagai, Y., Augustyns, K., de Meester, I., Haemers, A. \& Scharpé, S. (2003). Adv. Exp. Med. Biol. 524, 29-35.

Oefner, C., D'Arcy, A., Mac Sweeney, A., Pierau, S., Gardiner, R. \& Dale, G. E. (2003). Acta Cryst. D59, 1206-1212.

Ohtsuki, T., Hosono, O., Kobayashi, H., Munakata, A., Souta, A., Shinoda, T. \& Morimoto, C. (1998). FEBS Lett. 431, 236-240.

Otwinowski, Z. \& Minor, W. (1997). Methods Enzymol. 276, 307-326.

Potempa, J., Pike, R. \& Travis, J. (1995). Prosp. Drug Discov. Des. 2, 445-458.

Rasmussen, H. B., Branner, S., Wiberg, F. C. \& Wagtmann, N. (2003). Nature Struct. Biol. 10, 19-25.

Rawlings, N. D., Polgár, L. \& Barrett, A. J. (1991). Biochem. J. 279, 907-908.

Read, R. C. \& Finch, G. (1998).). Topley and Wilson's Principles of Bacteriology, Virology and Immunity, 9th ed., edited by W. J. Hausler \& M. Sussman, Vol. 3, pp. 319-345. London: Arnold.

Takahashi, N. \& Sato, T. (2001). J. Dent. Res. 80, 1425-1429.

Takahashi, N. \& Sato, T. (2002). Oral Microbiol. Immunol. 17, 50-54.

Thoma, R., Loffler, B., Stihle, M., Huber, W., Ruf, A. \& Hennig, M. (2003). Structure, 8, 947-59.

Travis, J., Pike, R., Imamura, T. \& Potempa, J. (1997). J. Periodontal. Res. 32, 120- 125.

Wrenger, S., Hoffmann, T., Faust, J., MrestaniKlaus, C., Brandt, W., Neubert, K., Kraft, M., Olek, S., Frank, R., Ansorge, S. \& Reinhold, D. (1997). J. Biol. Chem. 272, 30283-30288.

Yagashita, H., Kumagai, Y., Konishi, K., Takahashi, Y., Aoba, T. \& Yoshikawa, M. (2001). Infect. Immun. 69, 7159-7161. 